Eur. J. Clin. Chem. Clin. Biochem.

Vol. 32, 1994, pp. 501-509

(c) 1994 Walter de Gruyter \& Co.

Berlin · New York

\title{
Lipoamidase and Biotinidase Activities in the Rat: Tissue Distribution and Intracellular Localization ${ }^{1}$ )
}

\author{
By L. Nilsson and B. Kågedal \\ Department of Clinical Chemistry, University Hospital, Linköping, Sweden
}

(Received January 3/April 11, 1994)

Summary: Lipoamidase (not yet given an EC number) activity was measured in various rat tissues using two different substrates, one natural, lipoyllysine ( $\varepsilon-\mathrm{N}-(D, L$-lipoyl)- $L$-lysine) and one artificial, lipoyl-p-aminobenzoic acid (N-D,L-lipoyl-p-aminobenzoic acid). Biotinidase, EC 3.5.1.12, was measured in the same tissue with the artificial substrate, biotinyl-p-aminobenzoic acid (N-D-biotinyl-p-aminobenzoic acid). Lipoamidase measured as lipoyl-p-aminobenzoic acid hydrolase activity had two $\mathrm{pH}$ optima, at $\mathrm{pH} 6.0$ and $\mathrm{pH} 9.5$, in liver homogenate, but only one $\mathrm{pH}$ optimum at $\mathrm{pH} 6.0$ in rat plasma. Lipoamidase measured as lipoyllysine hydrolase activity had a $\mathrm{pH}$ optimum at $\mathrm{pH} 5.5$ both in liver homogenate and plasma. Similarly, biotinidase shows a single $\mathrm{pH}$ optimum at $\mathrm{pH}$ 6.0 in liver homogenate and plasma. The properties of lipoyllysine hydrolase and biotinidase were similar with respect to thermostability, $\mathrm{pH}$ stability and inhibition pattern, and their properties differed from those of lipoyl- $p$ aminobenzoic acid hydrolase.

Lipoyllysine hydrolase and biotinidase activities were highest in kidney, liver and blood plasma, whereas lipoyl-p aminobenzoic acid hydrolase activities were highest in liver, brain and kidney. Lipoyllysine hydrolase and biotinidase activities were found mainly in the liver microsomal fraction, and lipoyl-p-aminobenzoic acid hydrolase was recovered from the microsomal fraction and to a small extent from the mitochondrial fraction. These results indicate that liver lipoyl-p-aminobenzoic acid hydrolase is an enzyme protein which differs from lipoyllysine hydrolase, and the data also indicate that liver lipoyllysine hydrolase and biotinidase are the same enzyme protein.

\section{Introduction}

Lipoamidase $^{2}$ ) cleaves the lipoyllysine liberated after proteolytic degradation of 2-oxoacid dehydrogenase $(1-2)$. In early studies, lipoamidase activity was measured with lipoyllysine (I) as the natural substrate (fig. 1). Later, the presence of the enzyme in human serum and milk (3-6) was reported, using lipoyl-p-aminobenzoic acid (II) as an artificial substrate. The enzyme which splits lipoyllysine is here named lipoyllysine hydrolase and the one which splits lipoyl-p-aminobenzoic

\footnotetext{
1) Founding organisations:

The Swedish Medical Research Council

Thyra \& Thure Stenemark and Ruth Trossbecks Foundation

The Swedish Society of Medicine

2) Enzymes:

Biotinidase (EC 3.5.1.12)

Lipoamidase (Not yet given an EC number)
}

acid is named lipoyl-p-aminobenzoic acid hydrolase. Biotinidase ${ }^{2}$ ), which in analogy with lipoamidase, splits $\varepsilon$-N-biotinyllysine (biocytin, III) to biotin and lysine (7,

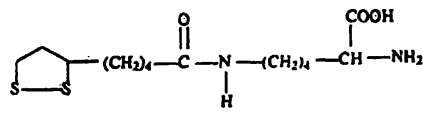

(I) Lipoyllysine

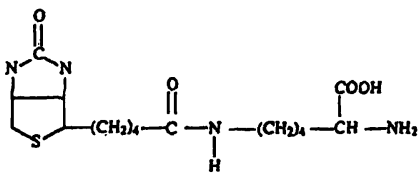

(III) Biocytin

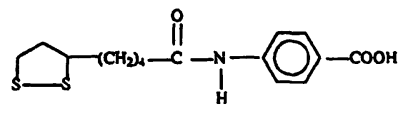

(II) Lipoyl-p-aminobenzoic acid

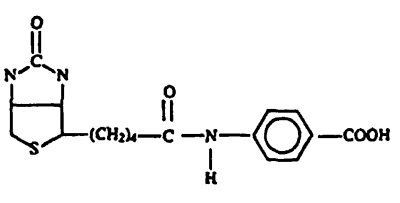

(IV) Biotinyl-p-aminobenzoic acid
Fig. 1 Structural formula of natural and synthetic substrates used for lipoyllysine hydrolase, lipoyl-p-aminobenzoic acid hydrolase and biotinidase assay. 
8), also cleaves the synthetic substrate, biotinyl-p-aminobenzoic acid (IV), frequently used as a substrate in assay methods for biotinidase (9).

When measured by their hydrolysis of both natural and artificial substrates, lipoamidase and biotinidase could not be separated from each other, despite 20000 -fold purification from serum. This suggests that there is one main enzyme protein which has both lipoamidase and biotinidase activities (10). This agrees with the finding of very low lipoamidase activity in the serum of a patient with biotinidase deficiency (11). However a "residual" activity was observed when lipoyl-p-aminobenzoic acid was used as a substrate (11), indicating the presence of a small amount of an isoenzyme of lipoamidase (lipoyl-X hydrolase).

In contrast to the enzyme found in human serum (3), lipoamidase identified in human milk with the artificial substrate lipoyl-p-aminobenzoic acid failed to split lipoyllysine. Furthermore, the enzyme in breast milk showed an inhibition pattern with sulphydryl reagents, which was different from that found for the enzyme in serum, indicating that two different enzymes might be measured with lipoyllysine and lipoyl-p-aminobenzoic acid as substrates (3). Using lipoyl-p-aminobenzoic acid as substrate, lipoamidase has also been measured in guinea pig liver and pig brain $(12,13)$, and it was claimed to be a serine protease localized in the microsomal fraction (12). Oizumi \& Hayakawa (12) reported that biotinidase and lipoamidase purified from guinea pig liver could be separated from each other.

As mentioned above, there are indications that lipoamidase and biotinidase in serum constitute one and the same enzyme, but separation of guinea pig liver lipoamidase from biotinidase (12), and the presence in milk (3) of a lipoamidase with properties different from that in serum suggest the presence of a second lipoamidase. The aim of the present study was to investigate the tissue distribution and intracellular localizations, and to determine the properties of biotinidase and lipoamidase in liver homogenates, the latter enzyme being measured with both natural and artificial substrates.

\section{Materials and Methods}

Chemicals and reagents

$\alpha$-Lipoic acid, $p$-aminobenzoic acid and cysteine hydrochloride were obtained from E. Merck (Darmstadt, Germany). Cysteamine hydrochloride and iodoacetamide were from Fluka AG (Buchs, Switzerland) and 2-glycerophosphate, p-chloromercuribenzoic acid, phenylmethanesulphonyl fluoride and acetyl- $L$-leucyl- $L$-leucyl- $L$-arginal (leupeptin) were from Serva (Heidelberg, Germany). $D$-Glucose-6-phosphate (dipotassium salt : hydrate), N-ethylmalei- . mide, 3,4-dichloroisocoumarin, $L$-trans-epoxysuccinyl- $L$-leucylamido(4-guanidino)butane (E-64), 1-chloro-3-tosylamido-7-amino-
L-2-heptanone (TLCK) and 1-chloro-3-tosylamido-4-phenyl-2-butanone (TPCK) were from Sigma (St. Louis, MO, USA).

Two commercial lots of diisopropylfluorophosphate from Serva were used. One lot, rated as "pure" (preparation A), contained about $90 \%$ of diisopropylfluorophosphate, whereas the other (preparation B), contained $6 \%$ of diisopropylfluorophosphate adsorbed to Kieselguhr, from which it was eluted by dimethylsulphoxide (final concentration $20 \mathrm{mmol} / \mathrm{l}$ ) according to instructions from the manufacturer. The concentration of diisopropylfluorophosphate in the eluate was assayed by enzyme inhibition of acetylcholine esterase (14) using an enzyme preparation from bovine erythrocytes obtained from Serva.

Lipoyllysine was prepared according to Nawa et al. (15). Lipoyl$p$-aminobenzoic acid and biotinyl-p-aminobenzoic acid were synthesized by a procedure similar to that used by Knappe et al. (16).

\section{Specimens}

Female Wistar rats $(200-300 \mathrm{~g})$ were obtained from ALAB Laboratorietjänst $\mathrm{AB}$ (Sollentuna, Sweden). Pairs of animals were housed in cages and had free access to chow and water. The animals were killed after being starved for $20-24 \mathrm{~h}$.

\section{Preparation of tissue homogenates}

The rats were anaesthetized with ether, and organ and tissues were quickly removed, chilled on ice and rinsed with $154 \mathrm{mmol} / \mathrm{h} \mathrm{NaCl}$. The tissues were weighed, minced and homogenized in cold $\left(+4{ }^{\circ} \mathrm{C}\right) 154 \mathrm{mmol} / \mathrm{l} \mathrm{NaCl}$ to give homogenates containing a tissue fraction of 0.1. Potter-Elvehjem homogenizers fitted with Teflon pestles were used. The tubes, kept on ice, were raised up and down 6 times during $1 \mathrm{~min}\left(2000 \mathrm{~min}^{-1}\right)$. Muscle tissue and tissues from the gastrointestinal tract were homogenized as before, but the procedure was repeated 4 times. Blood was collected by heart puncture into Vacutainer ${ }^{\circledR}$ tubes (Becton Dickinson, Rutherford, NJ, USA) containing heparin.

\section{Subcellular fractionation}

The liver was rapidly removed, chilled on ice and rinsed with cold $154 \mathrm{mmol} / \mathrm{h} \mathrm{NaCl}$. Liver tissue $(4 \mathrm{~g})$ was minced and homogenized in a Potter-Elvehjem homogenizer with $20 \mathrm{ml}$ cold $0.25 \mathrm{~mol} / 1$ sucrose solution containing $1 \mathrm{mmol} / \mathrm{l}$ EDTA. Subcellular fractionation of the homogenates was performed according to Bouma et al. (17).

Protein determination

Protein was determined by the method of Lowry et al. (18), with bovine serum albumin as calibrator.

\section{Assay of enzyme activity}

Enzyme activities were expressed in Units defined as the amount of enzyme which forms $1 \mu \mathrm{mol}$ of product per min. All enzyme assays were performed in duplicate at $37^{\circ} \mathrm{C}$.

\section{Lipoyllysine hydrolase activity}

Lipoyllysine hydrolase activity was determined as reported in detail previously $(3,10)$. In short, $0.5 \mathrm{ml}$ of homogenate was added to $1 \mathrm{ml}$ of a $50 \mathrm{mmol} / \mathrm{h}$ acetate buffer $\mathrm{pH} 4.86$ to give the intended $\mathrm{pH}$ of 5.5 after addition of substrate. The reaction was started by addition of lipoyllysine (final concentration $1 \mathrm{mmol} / \mathrm{l}$ ). After incubation for 1 hour the reaction was stopped by the addition of sulphuric acid. Liberated lipoic acid was then extracted and quantified by the Ellman reaction (19). The sénsitivity of this method calcu- 
lated as twice the absorbance of a blank sample was 0.13 mUnits. The $K_{\mathrm{m}}$ of lipoyllysine hydrolysis in crude liver homogenate was $1.3 \mathrm{mmol} / \mathrm{l}$.

\section{Lipoyl-p-aminobenzoic acid hydrolase activity}

Lipoyl-p-aminobenzoic acid hydrolase activity was determined with lipoyl-p-aminobenzoic acid as substrate $(3,10)$. Briefly, 25$100 \mu \mathrm{l}$ of homogenate was mixed with $1 \mathrm{ml}$ of $50 \mathrm{mmol} / \mathrm{l}$ phosphate buffer $\mathrm{pH} 5.68$ to give a final $\mathrm{pH}$ of 6.0 after addition of substrate. The reaction was started by addition of lipoyl-p-aminobenzoic acid (final concentration $0.75 \mathrm{mmol} / \mathrm{l}$ ), and after $30 \mathrm{~min}$ the reaction was terminated by the addition of trichloroacetic acid. The amount of liberated $p$-aminobenzoic acid was determined by the diazo-coupling method (20). The difference of absorbance $(\Delta \mathrm{A})$ at $546 \mathrm{~nm}$ was linear up to 1.2 , corresponding to $120 \mathrm{nmol} p$ aminobenzoic acid. The sensitivity of this method was $0.13 \mathrm{mUn}$ its. The corresponding $K_{m}$ values with the substrate lipoyl-p-aminobenzoic acid measured at $\mathrm{pH} 6.0$ and 9.5 in crude liver homogenate were 1.3 and $0.69 \mathrm{mmol} / \mathrm{l}$, respectively.

In some experiments the lipoyl-p-aminobenzoic acid hydrolase activity was measured at $\mathrm{pH} 9.5$, by changing the buffer to $50 \mathrm{mmol} / \mathrm{l}$ carbonate, $\mathrm{pH} 9.4$, which gave a final $\mathrm{pH}$ of 9.5 after addition of substrate.

\section{Biotinidase activity}

Biotinidase was determined according to Wolf et al. (9). The reaction tube contained $0.5 \mathrm{ml}$ homogenate and $1.0 \mathrm{ml}$ of $50 \mathrm{mmol} / \mathrm{l}$ phosphate buffer, pH 5.68 to give an intended pH of 6.0 after addition of substrate. The enzyme reaction was started by addition of biotinyl-p-aminobenzoic acid (final concentration $0.15 \mathrm{mmol} / \mathrm{l}$ ). After $30 \mathrm{~min}$, trichloroacetic acid was added and liberated $p$-aminobenzoic acid was assayed as described for lipoyl-p-aminobenzoic acid hydrolase. The sensitivity of this method was $0.11 \mathrm{mUn}$ its. The $K_{\mathrm{m}}$ value with the substrate biotinyl-p-aminobenzoic acid was $15 \mu \mathrm{mol} / 1$ when crude liver homogenate was used.

Biotinidase activity can be measured by using the natural substrate biotinyllysine, either by determination of liberated biotin or lysine, but these methods are cumbersome. Analysis of biotin requires available HPLC-equipment. Lysine can be determined fluorimetrically after derivatization with 1,2-diacetylbenzene, but this method requires that endogenous lysine is removed by dialysis prior to assay. In an earlier paper (10) biotinidase was measured in serum fractions by use of both natural (biotinyllysine) and artificial (biotinyl-p-aminobenzoic acid), and good agreement was found with the two methods. In the present paper therefore, only biotinyl$p$-aminobenzoic acid was used.

\section{Subcellular markers}

Acid phosphatase and glucose-6-phosphatasè were used as markers for subcellular particles. The activity of the lysosomal enzyme acid phosphatase was determined according to Trouet (21), and the activity of the microsomal enzyme glucose-6-phosphatase was measured according to Appelmans et al. (22).

\section{Effects of inhibitors, thiol compounds and EDTA}

For investigation of the susceptibility of the enzymes to inhibitors, $1.5-\mathrm{ml}$ aliquots of rat liver homogenate (tissue fraction 0.1 ) were incubated at $37^{\circ} \mathrm{C}$ for $10 \mathrm{~min}$ with $15 \mu \mathrm{l}$ of various compounds or with $20 \mu$ l of $p$-chloromercuribenzoic acid. The enzyme activity was then measured as in the standard assay, except that the assay buffer contained appropriate concentrations of inhibitors, so that the final inhibitor concentration was the same as in the preincubation mixture.

\section{pH stability}

Solutions of $154 \mathrm{mmol} / 1 \mathrm{NaCl}$ were prepared containing various amounts of $\mathrm{HCl}$ or $\mathrm{NaOH}$ to give $\mathrm{pH}$ values between 2 and 10 when $1 \mathrm{ml}$ of each solution was added to $1 \mathrm{ml}$ aliquots of liver homogenate (tissue fraction 0.2 ). After incubation for $1 \mathrm{~h}$ an aliquot was taken for lipoyllysine hydrolase, lipoyl-p-aminobenzoic acid hydrolase and biotinidase analysis. The assay buffer was chosen to give the same final $\mathrm{pH}$ as in the standard assay for lipoyllysine hydrolase, lipoyl-p-aminobenzoic acid hydrolase and biotinidase, respectively. The $\mathrm{pH}$ was checked at the end of each incubation to confirm that it had not changed.

\section{Thermostability}

Four tubes containing freshly prepared liver homogenate (tissue fraction 0.1) were incubated in a water-bath at 37, 50, 60 and $70^{\circ} \mathrm{C}$. From these mixtures appropriate portions were taken at various times for assay of enzyme activity.

\section{Results}

In preliminary experiments the highest lipoamidase activity was found in liver homogenates. The enzyme as-
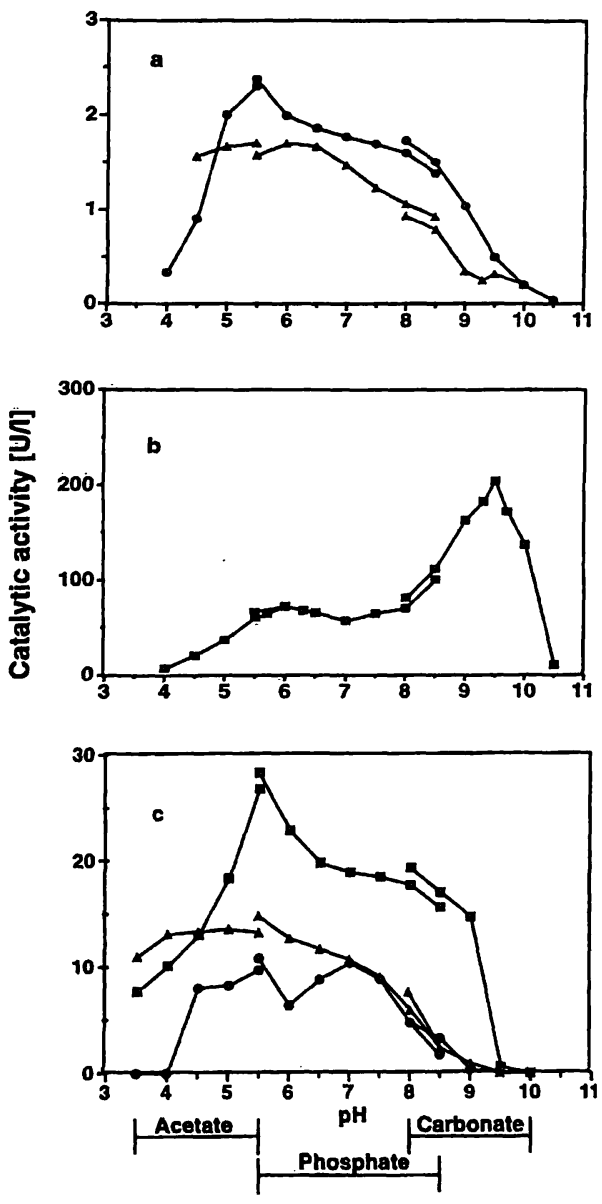

Fig. $2 \mathrm{pH}$ optimum of lipoyllysine hydrolase, lipoyl-p-aminobenzoic acid hydrolase and biotinidase in $(a, b)$ rat liver homogenate and (c) rat plasma.

Reaction conditions were those of the standard assay for lipoyllysine hydrolase $(\bullet-\bullet)$, lipoyl-p-aminobenzoic acid hydrolase $(\boldsymbol{\square}-\boldsymbol{\square})$ and biotinidase $(\boldsymbol{\Delta}-\mathbf{\Delta})$ except for $\mathrm{pH}$. Buffer solutions, 50 $\mathrm{mmol} / \mathrm{l}$ are indicated in the figure. Values given are the mean from two experiments. 
says were therefore optimized with rat liver as the enzyme source.

\section{pH optimum}

Lipoyllysine hydrolase in liver homogenate could be measured within a broad $\mathrm{pH}$ range with an optimum at pH 5.5 (fig. 2a). A similar profile was obtained with rat plasma (fig. 2c). As illustrated in figure $2 b$, lipoyl-paminobenzoic acid hydrolase from liver homogenate had two $\mathrm{pH}$ optima. The measuring range for serum lipoyl$p$-aminobenzoic acid hydrolase was also broad with an optimum at pH 5.5 (fig. $2 \mathrm{~b}$ ). In contrast to lipoyl-p-aminobenzoic acid hydrolase in liver, lipoyl-p-aminobenzoic acid hydrolase in serum was nearly inactive at $\mathrm{pH}$ 9.5 , as shown in figure $2 \mathrm{c}$. Biotinidase in liver homogenate and serum had a broad $\mathrm{pH}$ range (fig. $2 \mathrm{a}$ and $2 \mathrm{c}$ ).

\section{Dependence on enzyme amounts and reaction time is}

The hydrolysis of lipoyllysine by liver homogenate was zero order for at least $90 \mathrm{~min}$ and the amount of lipoate released per unit of time was linearly related to the amount of liver homogenate at least up to $0.6 \mathrm{ml}$ of liver homogenate (volume fraction 0.1 ) in the assay. The splitting (hydrolysis) of lipoyl-p-aminobenzoic acid (at pH 6.0) and of biotinyl-p-aminobenzoic acid was linearly related to the incubation time for at least $60 \mathrm{~min}$. The amounts of liberated $p$-aminobenzoic acid were linearly related to the quantity of homogenate, at least up to $0.15 \mathrm{ml}$ and $0.6 \mathrm{ml}$ of liver homogenate (tissue fraction 0.1$)$ in the respective assays. When lipoyl-p-amino-

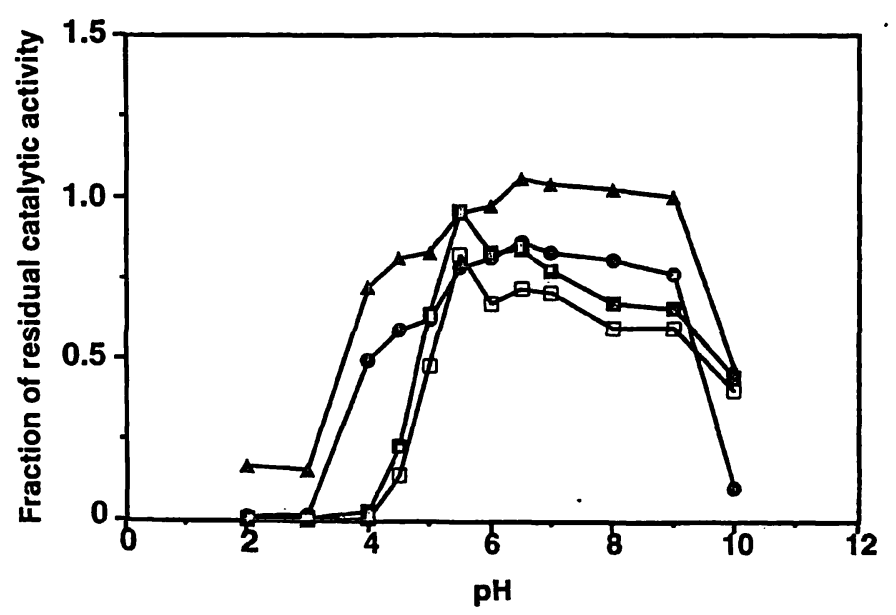

Fig. 3 pH stability test.

Equal volumes of homogenate (tissue fraction 0.2 ) and $\mathrm{HCl}$ or $\mathrm{NaOH}$ solutions containing $154 \mathrm{mmol} / \mathrm{l} \mathrm{NaCl}$ were mixed to give the appropriate $\mathrm{pH}$ and incubated for one hour. The remaining enzyme activities are given as fraction of initial value.

Reaction conditions were those of the standard assays for lipoyllysine hydrolase $(\mathbf{0}-\bullet)$, lipoyl-p-aminobenzoic acid hydrolase, $\mathrm{pH}$

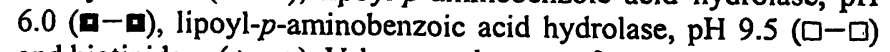
and biotinidase $(\mathbf{\Lambda}-\mathbf{\Lambda})$. Values are the mean from two experiments. benzoic acid hydrolase was measured at $\mathrm{pH} 9.5$ the reaction was zero order up to $30 \mathrm{~min}$; the curve then deviated from linearity, probably because of deviation from the Lambert Beer's law. The amount of $p$-aminobenzoic acid formed was linearly related to the quantity of homogenate, up to at least $40 \mu \mathrm{l}$ of liver homogenate (volume fraction 0.1 ) in the assay.

\section{pH stability}

Figure 3 shows the pH stability of lipoamidase and biotinidase. The $\mathrm{pH}$ stability of lipoyllysine hydrolase and biotinidase were similar but differed markedly from that of lipoyl-p-aminobenzoic acid hydrolase measured both at $\mathrm{pH} 6.0$ and $\mathrm{pH} 9.5$.
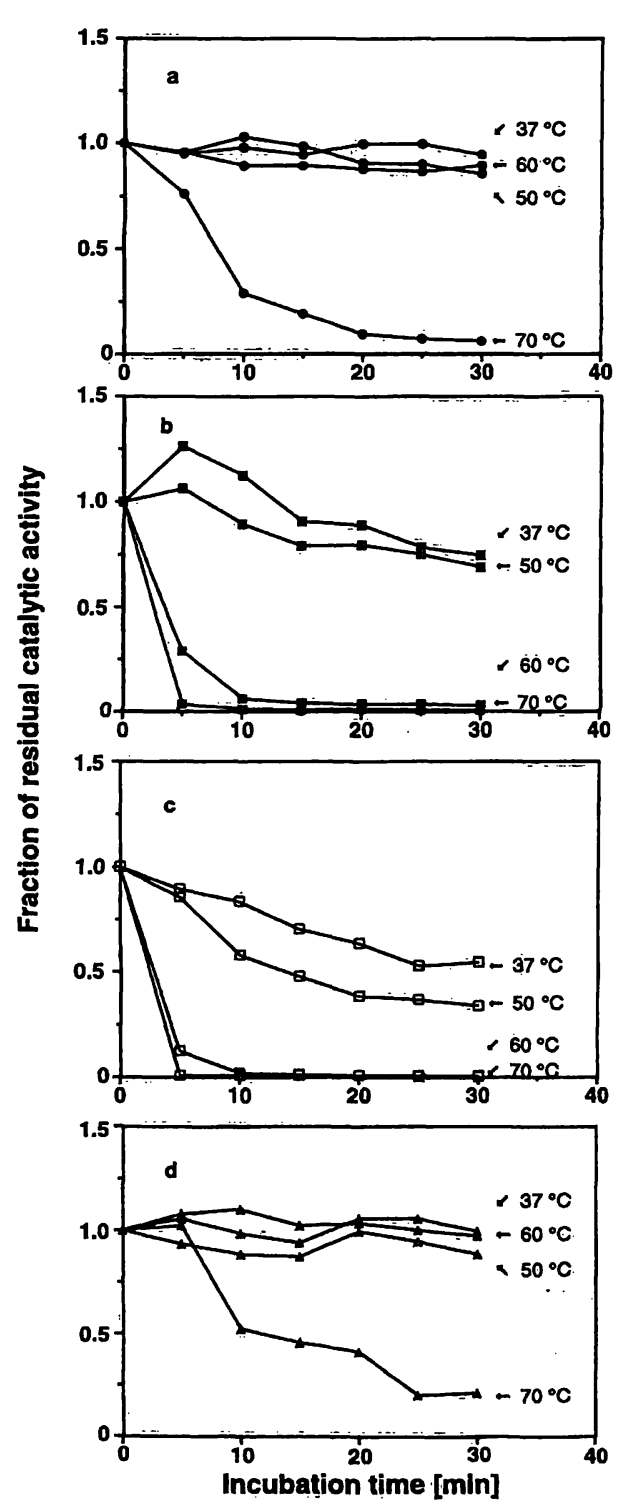

Fig. 4 Thermostability test.

Aliquots of liver homogenates were preincubated at different temperatures for various times as indicated in the figure. Other reaction conditions were as in the standard assay. The enzyme activities are relative to initial values. (a) lipoyllysine hydrolase, (b) lipoyl-paminobenzoic acid hydrolase assayed at $\mathrm{pH}$ 6.0, (c) lipoyl-p-aminobenzoic acid hydrolase assayed at $\mathrm{pH} 9.5$, and (d) biotinidase. Values given are the means from two experiments. 


\section{Thermostability test}

Figure 4 shows the thermostability of lipoyllysine hydrolase, lipoyl-p-aminobenzoic acid hydrolase and biotinidase from liver. The lipoyllysine hydrolase and biotinidase thermostability curves were similar and the activities were stabile during incubation at temperatures up to $60^{\circ} \mathrm{C}$. With incubation at $70^{\circ} \mathrm{C}$ the activities descreased to about $20-50 \%$ of initial values after 10 $\mathrm{min}$, and at $60^{\circ} \mathrm{C}$ the enzymes were stable for $30 \mathrm{~min}$. Lipoyl-p-aminobenzoic acid hydrolase was rapidly inactivated at $60^{\circ} \mathrm{C}$ when measured at $\mathrm{pH} 6.0$ or $\mathrm{pH} 9.5$.

\section{Effects of thiol compounds, sulphydryl reagents and EDTA}

No significant stimulation of lipoyllysine hydrolase, lipoyl-p-aminobenzoic acid hydrolase and biotinidase from liver homogenate was observed by the thiol compounds tested (tab. 1). In general, sulphydryl reagents at high concentrations $(1 \mathrm{mmol} / \mathrm{l})$ were strong inhibitors of lipoyllysine hydrolase, lipoyl-p-aminobenzoic acid hydrolase and biotinidase. Particulary $\mathrm{Cu}^{2+}, \mathrm{Hg}^{+}$and $p$ chloromercuribenzoic acid strongly inactivated lipoyl-paminobenzoic acid hydrolase when measured at $\mathrm{pH} 9.5$.
Effects of protease inhibitors are summarizied in table 2 . The serine protease inhibitors, diisopropylfluorophosphate, phenylmethanesulphonyl fluoride and dichloroisocoumarin inhibited the enzymes, but the degree of inhibition varied, and the two diisopropylfluorophosphate preparations gave somewhat different results. Phenylmethanesulphonyl fluoride at concentrations higher than $0.1 \mathrm{mmol} / \mathrm{l}$ strongly inhibited lipoyl-p-aminobenzoic acid hydrolase, but this was not the case with lipoyllysine hydrolase and biotinidase. The same tendency was observed with dichloroisocoumarin, a recently described serine protease inhibitor (22).

\section{Enzyme activities in rat tissues}

As shown in table 3, the rat tissue distributions of lipoyllysine hydrolase and lipoyl-p-aminobenzoic acid hydrolase were quite different. Generally, the lipoyllysine hydrolase and biotinidase activities were lower than lipoyl-p-aminobenzoic acid hydrolase activity. The lipoyllysine hydrolase activity was highest in kidney, followed by liver and plasma. When lipoamidase was assayed as lipoyl-p-aminobenzoic acid hydrolase a rather different enzyme pattern was observed. The highest enzyme activity was obtained when the assay was performed at $\mathrm{pH}$

Tab. 1 Effect of thiol compounds, sulphydryl reagents and EDTA on lipoamidase and biotinidase activity in rat liver homogenate

\begin{tabular}{|c|c|c|c|c|c|}
\hline \multirow[t]{2}{*}{ Compound } & \multirow{2}{*}{$\begin{array}{l}\text { Concentration } \\
(\mathrm{mmol} / \mathrm{l})\end{array}$} & \multicolumn{4}{|c|}{ Enzyme activity* } \\
\hline & & $\begin{array}{l}\text { Lipoyllysine } \\
\text { hydrolase }\end{array}$ & $\begin{array}{l}\text { Lipoyl-p- } \\
\text { aminobenzoic } \\
\text { acid hydrolase } \\
\text { (pH 6.0) }\end{array}$ & $\begin{array}{l}\text { Lipoyl-p- } \\
\text { aminobenzoic } \\
\text { acid hydrolase } \\
\text { (pH 9.5) }\end{array}$ & Biotinidase \\
\hline Cysteine & 1.0 & 98 & 102 & 104 & 107 \\
\hline Glutathione & 1.0 & 109 & 96 & 100 & 115 \\
\hline Cysteamine & 1.0 & 102 & 96 & 54 & 101 \\
\hline EDTA & 1.0 & 100 & 108 & 103 & 104 \\
\hline $\mathrm{NaCl}$ & 10.0 & 101 & 101 & 88 & 102 \\
\hline $\mathrm{CuSO}_{4}$ & 1.0 & 5 & 1 & 0 & 9 \\
\hline $\mathrm{CuSO}_{4}$ & 0.1 & 82 & $i$ & 0 & 92 \\
\hline $\mathrm{CuSO}_{4}$ & 0.01 & 94 & 66 & 9 & 99 \\
\hline $\mathrm{CuSO}_{4}$ & 0.001 & n.d.** & 86 & 57 & n.d.** \\
\hline $\mathrm{Hg}_{2} \mathrm{Cl}_{2}$ & 1.0 & 4 & 2 & 0 & 14 \\
\hline $\mathrm{Hg}_{2} \mathrm{Cl}_{2}$ & 0.1 & 93 & 4 & 0 & 41 \\
\hline $\mathrm{Hg}_{2} \mathrm{Cl}_{2}$ & 0.01 & 97 & 58 & 7 & 102 \\
\hline $\mathrm{Hg}_{2} \mathrm{Cl}_{2}$ & 0.001 & n. d.** & 92 & 61 & n. d. $* *$ \\
\hline Iodoacetamide & 1.0 & 6 & 81 & 3 & 11 \\
\hline lodoacetamide & 0.1 & 54 & 89 & 26 & 34 \\
\hline Iodoacetamide & 0.01 & 94 & 95 & 59 & 102 \\
\hline N-Ethylmaleimide & 1.0 & 5 & 21 & 1 & 15 \\
\hline N-Ethylmaleimide & 0.1 & 7 & 59 & 15 & 94 \\
\hline N-Ethylmaleimide & 0.01 & 91 & 85 & 58 & n. d. $* *$ \\
\hline$p$-Chloromercuribenzoate & 1.0 & 0 & 0 & 0 & 16 \\
\hline$p$-Chloromercuribenzoate & 0.1 & 7 & 0 & 2 & 18 \\
\hline$p$-Chloromercuribenzoate & $0: 01$ & 45 & 75 & 62 & 32 \\
\hline$p$-Chloromercuribenzoate & 0.001 & 88 & 99 & 100 & 85 \\
\hline
\end{tabular}

* Enzyme activities are given as \% of control. Values are the mean from two experiments.

** Not determined. 
Tab. 2 Effect of protease inhibitors on lipoamidase and biotinidase activities in rat liver homogenate

\begin{tabular}{|c|c|c|c|c|c|}
\hline \multirow[t]{2}{*}{ Compound } & \multirow{2}{*}{$\begin{array}{l}\text { Concentration } \\
(\mathrm{mmol} / \mathrm{l})\end{array}$} & \multicolumn{4}{|c|}{ Enzyme activity* } \\
\hline & & $\begin{array}{l}\text { Lipoyllysine } \\
\text { hydrolase }\end{array}$ & $\begin{array}{l}\text { Lipoyl-p- } \\
\text { aminobenzoic } \\
\text { acid hydrolase } \\
\text { (pH 6:0) }\end{array}$ & $\begin{array}{l}\text { Lipoyl-p- } \\
\text { aminobenzoic } \\
\text { acid hydrolase } \\
\text { (pH 9.5) }\end{array}$ & Biotinidase \\
\hline Diisopropylfluorophosphate** & 1.0 & 6 & 2 & 0 & 0 \\
\hline Diisopropylfluorophosphate** & 0.1 & 40 & 3 & 0 & 11 \\
\hline Diisopropylfluorophosphate** & 0.01 & 82 & 57 & 7 & 69 \\
\hline Diisopropylfluorophosphate*** & 1.0 & 96 & 65 & 27 & 106 \\
\hline Diisopropylfluorophosphate*** & 0.1 & 104 & 104 & 80 & 106 \\
\hline Phenylmethanesulphonyl fluoride & 1.0 & 51 & 3 & 2 & 62 \\
\hline Phenylmethanesulphonyl fluoride & 0.1 & 90 & 5 & 12 & 99 \\
\hline Phenylmethanesulphonyl fluoride & 0.01 & 98 & 22 & 33 & 105 \\
\hline Phenylmethanesulphonyl fluoride & 0.001 & n. d.**** & 84 & n.d. $* * * *$ & n.d.**** \\
\hline Dichloroisocoumarin & 1.0 & 16 & 7 & 1 & 23 \\
\hline Dichlorosiocoumarin & 0.1 & 93 & 38 & 9 & 85 \\
\hline Dichloroisocoumarin & 0.01 & n. d. **** & 64 & 58 & 94 \\
\hline $\begin{array}{l}\text { 1-Chloro-3-tosylamido-7-amino- } \\
\text { L-2-hepanone }\end{array}$ & 1.0 & 4 & 78 & 72 & 15 \\
\hline $\begin{array}{l}\text { 1-Chloro-3-tosylamido-7-amino- } \\
\text { L-2-hepanone }\end{array}$ & 0.1 & 8 & 80 & 80 & 23 \\
\hline $\begin{array}{l}\text { 1-Chloro-3-tosylamido-7-amino- } \\
\text { L-2-hepanone }\end{array}$ & 0.01 & 60 & n. d. $* * * *$ & n. d. $* * * *$ & 81 \\
\hline $\begin{array}{l}\text { 1-Chloro-3-tosylamido-4-phenyl- } \\
\text { 2-butanone }\end{array}$ & 1.0 & 9 & 28 & 1 & 17 \\
\hline $\begin{array}{l}\text { 1-Chloro-3-tosylamido-4-phenyl- } \\
\text { 2-butanone }\end{array}$ & 0.1 & 5 & 59 & 5 & 41 \\
\hline $\begin{array}{l}\text { 1-Chloro-3-tosylamido-4-phenyl- } \\
\text { 2-butanone }\end{array}$ & 0.01 & 42 & 99 & 105 & 101 \\
\hline $\begin{array}{l}L \text {-trans-Epoxysuccinyl- } L \text {-leucyl- } \\
\text { amido(4-guanidino)butane }\end{array}$ & 0.1 & 107 & 102 & 83 & 97 \\
\hline Leupeptin & 0.1 & 98 & 101 & 82 & 98 \\
\hline
\end{tabular}

* Enzyme activities are given as \% of control. Values are the mean from two experiments.

** Diisoproylfluorophosphate preparation rated as pure (see Material and Methods).

*** Diisoproylfluorophosphate preparation from Kieselguhr (see Material and Methods).

$* * * *$ Not determined.

Tab. 3 Lipoamidase and biotinidase activities in rat tissues

\begin{tabular}{|c|c|c|c|c|}
\hline \multirow[t]{2}{*}{ Tissue } & \multicolumn{4}{|c|}{ Enzyme activity* } \\
\hline & $\begin{array}{l}\text { Lipoyllysine } \\
\text { hydrolase }\end{array}$ & $\begin{array}{l}\text { Lipoyl-p-aminobenzoic } \\
\text { acid hydrolase (pH 6.0) }\end{array}$ & $\begin{array}{l}\text { Lipoyl-p-aminobenzoic } \\
\text { acid hydrolase (pH 9.5) }\end{array}$ & Biotinidase \\
\hline Kidney & $27(24-27)$ & $27(27-33)$ & $40(22-43)$ & $22(19-24)$ \\
\hline Liver & $16(16-18)$ & $335(237-383)$ & $1190(797-1499)$ & $18(15-18)$ \\
\hline Plasma & $11(11-12)$ & $19(14-20)$ & $1(1-3)$ & $13(13-14)$ \\
\hline Spleen & $8(8-11)$ & $15(12-18)$ & $19(12-20)$ & $9(8-10)$ \\
\hline Stomach & $7(5-11)$ & $13(7-14)$ & $5(3-12)$ & $8(8-8)$ \\
\hline Heart & $8(7-8)$ & $16(13-16)$ & $3(3-$ & $4(4-5)$ \\
\hline Lung & $9(4-9)$ & $17(16-22)$ & $13(11-22)$ & $8(7-8)$ \\
\hline Pancreas & $6(5-10)$ & $15(15-17)$ & $4(4-10)$ & $5(4-5)$ \\
\hline Small intestine & $7(2-12)$ & $22(17-29)$ & $5(2-8)$ & $9(7-9)$ \\
\hline Brain & $7(5-7)$ & 38. $(34-39)$ & $108(87-114)$ & $3(2-3)$ \\
\hline Large intestine & $6(4-7)$ & $11(7-13)$ & $4(4-5)$ & $6(6-7)$ \\
\hline Diaphragm & $4(4-5)$ & $11(4-12)$ & $19(4-26)$ & $3(3-4)$ \\
\hline Thigh muscle & $1(1-2)$ & $1(1-2)$ & $2(1-3)$ & $1(1-2)$ \\
\hline
\end{tabular}

* Enzyme activity was expressed as mUnits/g of fresh tissue. The results are given as median values from three experiments with ranges given within brackets.

9.5, with the highest activity being found in liver and brain, followed by kidney. Activities measured at $\mathrm{pH} 9.5$ were higher than those measured at $\mathrm{pH} 6.0$; lipoyl-paminobenzoic acid hydrolase activity was up to 4 -fold 
higher in liver and up to 3 -fold higher in brain. The distribution of biotinidase activities was, however, similar to that of lipoyllysine hydrolase activities.

\section{Enzyme activity in subcellular fractions}

Intracellular distribution of lipoyllysine hydrolase activity was similar to that of biotinidase (tab. 4), and the specific activities of both enzymes were high in the microsome and lysosome fractions. The lipoyl-p-aminobenzoic acid hydrolase, assayed at $\mathrm{pH} 6.0$ and $\mathrm{pH} 9.5$, was mainly distributed in mitochondria and microsomes.

\section{Discussion}

In the present study, experiments at various temperatures, pHs and with different inhibitors indicate that rat liver lipoyllysine hydrolase (lipoamidase) and biotinidase are due to the same enzyme protein, whereas lipoyl-p-aminobenzoic acid hydrolase is a different enzyme.

Hayakawa \& Oizumi (12) purified lipoamidase and biotinidase from guinea pig liver. They found that purified lipoamidase failed to split biotinyl-p-aminobenzoic acid, and purified biotinidase failed to split lipoyl-p-aminobenzoic acid, indicating that these enzymes are different in guinea pig liver. However, it was not considered whether lipoyllysine could be hydrolysed by purified lipoamidase or biotinidase from guinea pig liver.

Hayakawa \& Oizumi $(5,6)$ determined lipoamidase activity in human serum and breast milk by using lipoyl$p$-aminobenzoic acid as substrate. We recently found that the enzyme from human breast milk splits lipoyl-paminobenzoic acid but not lipoyllysine at pH 6.5 even without activators in the assay (3).

Recently we purified lipoamidase and biotinidase 20000 -fold from human serum, taking advantage of two substrates for both lipoamidase and biotinidase (10). The purified product had high activity with lipoyllysine, lipoyl-p-aminobenzoic acid, biotinyllysine and biotinyl-paminobenzoic acid, indicating that most of the lipoamidase and biotinidase activity in human serum is due to the same enzyme protein (10). It is therefore tempting to suggest that the lypoyllysine hydrolase and biotinidase from liver are one and the same enzyme.

The tissue and intracellular distribution of lipoyllysine hydrolase and biotinidase were similar (tab. 3 and 4). The highest lipoyl-p-aminobenzoic acid hydrolase activity (at $\mathrm{pH}$ 9.5) was found in liver and was about 4-fold higher than lipoyl-p-aminobenzoic acid hydrolase (at $\mathrm{pH}$ 6.0 ), whereas the enzyme activity in serum was practically inactive at $\mathrm{pH}$ 9.5. This indicates that lipoyl-p-

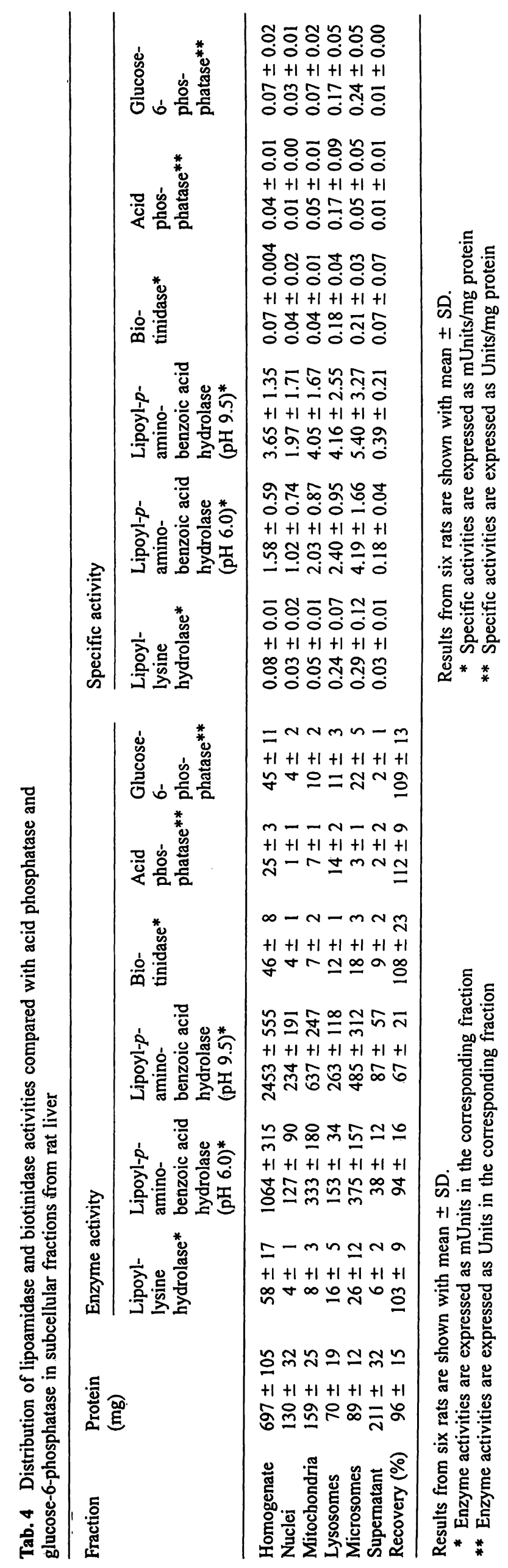


aminobenzoic acid hydrolase exists as two isoenzymes in the liver and that lipoyl-p-aminobenzoic acid hydrolase with a $\mathrm{pH}$ optimum at $\mathrm{pH} 6.0$ is probably the same lipoyl-p-aminobenzoic acid hydrolase as found in plasma.

The highest specific activities of lipoyllysine hydrolase and biotinidase were found in the microsomal fractions and lysosomes and not in the mitochondrial fraction. The specific activities of lipoyl-p-aminobenzoic acid hydrolase were similar in the mitochondrial fraction and in lysosomes. The lysosomal fraction was however contaminated with microsomes, as shown by electron microscopic examination (not shown). In agreement with other investigators $(12,24)$, we suggest that lipoyllysine hydrolase and biotinidase are mostly localizied in the microsomal fraction, whereas lipoyl-p-aminobenzoic acid hydrolase is distributed in both microsomes and mitochondria.

From the results obtained we suggest that lipoyllysine hydrolase and biotinidase activity in rat liver are due to the same enzyme, whereas lipoyl-p-aminobenzoic acid hydrolase is another enzyme. Consequently, lipoyllysine hydrolase and lipoyl-p-aminobenzoic acid hydrolase activities in rat liver are not due to one genuine "lipoa-

\section{References}

1. Reed, L. J., Koike, M., Levitch, M. E. \& Leach, F. R. (1958) Studies on the nature and reactions of protein-bound lipoic acid. J. Biol. Chem. 232, 143-158.

2. Suzuki, K. \& Reed, L. J. (1963) Lipoamidase. J. Biol. Chem. 238, 4021-4025.

3. Backman-Gullers, B., Hannestad, U., Nilsson, L. \& Sörbo, B. (1990) Studies on lipoamidase: Characterization of the enzymie in human serum and breast milk. Clin. Chim. Acta 191, 49-60.

4. Hayakawa, K. \& Oizumi, J. (1987) Determination of lipamidase activity by liquid chromatography with fluorimetric detection. J. Chromatogr. 423, 304-307.

5. Hayakawa, K. \& Oizumi, J. (1988) Human serum lipoamidase. Enzyme 40, 30-36.

6. Hayakawa, K. \& Oizumi, J. (1988) Isolation and characterization of human breast milk lipoamidase. Biochim. Biophys. Acta 957, 345-351.

7. Wright, L. D., Driscoll, C. A. \& Boger, W. P. (1954) Biocytinase, an enzyme concerned with hydrolytic cleavage of biocytin. Proc. Soc. Exp. Biol. Med. 86, 335-337.

8. Thoma, R. W. \& Peterson, W. H. (1954) The enzymatic degradation of soluble bound biotin. J. Biol. Chem. 210, 569-579.

9. Wolf, B., Grier, R. E., Allen, R. J., Goodman, S. I. \& Kien, C. L. (1983) Biotinidase deficiency: The enzymatic defect in lateonset multiple carboxylase deficiency. Clin. Chim. Acta 13I, 273-281.

10. Nilsson, L. \& Kågedal, B. (1993) Co-purification of human serum lipoamidase and biotinidase: Evidence that the two enzyme activities are due to the same enzyme protein. Biochem. J. 291, 545-551.

11. Nilsson, L. and Ronge, E. (1992) Lipoamidase and biotinidase deficiency: Evidence that lipoamidase and biotinidase are the midase". Thus the term "lipoamidase" should not be used for the enzyme which hydrolyses the artificial substrate lipoyl-p-aminobenzoic acid. Because we do not yet know the biological function of this enzyme, we prefer the names lipoyl-p-aminobenzoic acid hydrolase and lipoyl-X hydrolase, the latter: being first suggested by Reed (1). Recently Hui et al. (26) reported that human milk lipoamidase is identical to cholesterol esterase, and Oizumi \& Hayakawa (13) reported the amino acid composition of purified lipoamidase from pig brain, which is similar to that of the acetylcholine receptor from Electrophorus electricus. Such findings may give rise to interesting speculations, but to clarify the biological function of lipoyl- $p$-aminobenzoic acid hydrolase and its relation to the above mentioned enzyme and receptor, the lipoyl-X hydrolase has to be purified and characterized.

\section{Acknowledgement}

This work was supported by grants from the Swedish Medical Research Council (projects B92-13X-05644-13A and B93-13X05644-14B), grants from the Thyra \& Thure Stenemark and Ruth Trossbecks Foundation, and from The Swedish Society of Medicine (Svenska Läkaresällskapets Forskningsfonder). We also wish to acknowledge Mrs Birgit Backman-Gullers, and Ann Christin Granath for technical assistance, and Mr Ulf Hannestad for generous help during the synthesis of substrates. same enzyme in human serum. Eur. J. Clin. Chem. Clin. Biochem. 30, 119-126.

12. Oizumi, J. \& Hayakawa, K. (1989) Biotinidase and lipoamidase in guinea pig livers. Biochim. Biophys. Acta 991, 410414.

13. Oizumi, J. \& Hayakawa, K. (1990) Lipoamidase (lipoyl-Xhydrolase) from pig brain. Biochem. J. 266, 427-434.

14. Hammond, P. S. \& Forster, J. S. (1989) A microassay-based procedure for measuring low levels of toxic organophosphorus compounds through acetylcholine esterase inhibition. Anal. Biochem. 180, 380-383.

15. Nawa, H., Brady, W. T., Koike, M. \& Reed, L. J. (1960) Studies on the nature of protein-bound lipoic acid. J. Am. Chem. Soc. 82, 896-903.

16. Knappe, J., Brümmer, W. \& Biederbick, K. (1963) Reinigung und Eigenschaften der Biotinidase aus Schweinenieren und Lactobacillus Casei. Biochem. Z. 338, 599-613.

17. Bouma, J. M. W. \& Gruber, M. (1966) Intracellular distribution of cathepsin B and cathepsin $C$ in rat liver. Biochim. Biophys. Acta 113, 350-358.

18. Lowry, O. H., Rosebrough, N. J., Farr, A. L. \& Randall, R. J. (1951) Protein measurement with the Folin phenol reagent. J. Biol. Chem. 193, 265-275.

19. Ellman, G. \& Lysko, H. (1979) A precise method for the determination of whole blood and plasma sulfhydryl groups. Anal. Biochem. 93, 98-102

20. Bratton, A. C. \& Marshall, E. K. (1939) A new coupling component for sulfanilamide determination. J. Biol. Chem. 128, 537-550.

21. Trouet, A. (1974) Isolation of modified liver lysosomes. Meth= ods in Enzymology XXXI, 323-329. 
22. Appelmans, F., Wattiaux, R. \& de Duve, C. (1955) Tissue fractionation studies. 5. The association of acid phosphatase with a special class of cytoplasmic granules in rat liver. Biochem. J. $59,438-445$.

23. Gould, N. R. \& Liener, I. E. (1965) Reaction of ficin with diisopropylphosphorofluoridate. Evidence for a contaminating inhibitor. Biochemistry 4, 90-98.

24. Pispa, J. (1965) Animal biotinidase. Ann. Med. Exp. Biol. Fenn. 43, Suppl. 5, 5-39.

25. Chauhan, J. \& Dakshinamurti, K. (1986) Purification and characterization of human serum biotinidase. J. Biol. Chem. 262, 4268-4275.
26. Hui, D. Y., Hayakawa, K. \& Oizumi, J. (1993) Lipoamidase activity in normal and mutagenized pancreatic cholesterol esterase (bile salt-stimulated lipase). Biochem. J. 291, 65-69.

Dr. Lennart Nilsson

Department of Clinical Chemistry

Universitetssjukhuset

S-581 85 Linköping

Sweden 
. 